\title{
アルミナ顆粒粉の加圧流動成形
}

高橋 清造的1, 金井浩的1, 中川 威雄放2

的1 日本大学生産工学部, 干275 習志野市泉町1-2-1.

辞2 東京大学生産技術研究所, 干106 港区六本木7-22-1.

\section{Press Powder Flow Compaction of Alumina Granule}

\author{
Seizo Takahashi ${ }^{\text {r } 1}$, Hiroshi Kanai ${ }^{231}$ and Takeo Nakagawa \\ it Col. Ind. Tech., Nihon University, 1-2-1 Izumi-cho, Narashino 275. \\ t>2 Inst. Ind. Sci., University of Tokyo, 7-22-1 Roppongi Minato-ku, Tokyo 106.
}

Received January 11, 1993

\begin{abstract}
Deep cup shaped compact were formed by a uniaxial hydraulic press from alumina granule guranulated with small amount of resin binder PVA (Polyvinyl Alchohol) after admixing liquid paraffin. This granule could be automatically filled into a die cavity. In the case of green compact formed from granule with the sufficient flowability, the densified powder flowed from the bottom to the cup wall during compaction, and the difference in partial density of green compact could be reduced. This is caused by reason that liquid paraffin affects the lubrication between powders during compaction. When the difference in partial density of green compact was small, the diameter of sintered compact along the bottom to cup wall was shrinked uniformly from green compact.
\end{abstract}

\section{1 はじめに}

セラミックスの優れた酎熟性, 高強度, 電気絶緑性 を活用した機械部品としての用途は増加しつつある. セラミックス部品の製造方法は粉末治金法が唯一の方 法であり，粉末射出成形を含めて，各種の成形方法が 行われている. セラミックス粉末の成形法のうち乾式 ブレス成形法は従来から広く行われており，樹脂パイ ンタによつて造粒されたセラミックス粉末の顆粒粉を 金型プレス成形している. 成形に際し成形体に発生す る欠䧄や烧結時に起る欠宿の多くは, 成形時の顆粒粉
間および顆粒粉と金型との間の摩擦にともなう顆粒粉 の流動・移動が不十分であることに起因する.もし成 形中の顆粒粉が金型内において流動できたならは，成 形体内部の密度分布は㳚少し, 焼結時に発生する欠陷 の多くは解消でき，成形できる成形体の形状は従来の 乾式プレス成形法より大きく拡大できる.

加圧流動成形法は著者の一人である中川らが開発し

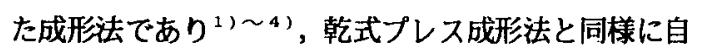
動給粉のできる顆粒粉を成形する：本成形法の特徵は 少量の樹脂バインダで造粒された顆粒粉に液状バイン 
タを添加混合した顆粒粉を乾式法にて単軸ブレス成形 する. 成形時の顆柆粉は添加された液状バインタの潤 滑効果により粉末間の摩擦およひ㸮末と金型の摩擦が 減少し，成形途中の顆粒粉は成形体内の高密度部から 低密度部へ流動し，成形体内部の密度差が少なく，か つ得られた成形体は高密度である。

本報は酸化物系セラミックスのアルミナ顆粒粉を加 区流動成形実験し，焼結体の寸法収縮について検討し た結果について報告する. 生粉末は粉碚された微粉末 であり焼結性が優れていることを考虑し，成形体の高 密度化よりは本成形法による成形体内部の密度分布の 均一化を目的に成形実駼を行い，得られた成形体は焼 結し，収維後の焼結体の直径を評価した。

\section{2 实䊖方法}

Fig.1 に本成形法の概略を示す. 成形に使用した共 試物末はPVA（ポリビニルアルコール）によって造粒 された顆粒粉であり，平均粒经は約 $100 \mu \mathrm{m}$ (Table 1) となっている. 顆粒粉は液状バインダとして流動パラ フィンを最大 $10 \mathrm{wt} \%$ で添加後に成形した. 成形は単 軸の油压プレスを使用し，12gfの顆粒粉を成形压: 98 MPa〜294MPaにて10sec間保持するフローディングダイ 法とした. 金型の阔滑はステアリン酸西鉊アルコール 溶液を望付した. 成形体はFig.2に示した薄肉カップ であり,カッブ壁の肉厚は $3 \mathrm{~mm}$ となっている. 成形体 の評価は外観の観察, 成形体全体の密度測定, 成形体

Table 1 Particle size distributions of alumina granule with 3wt\% PVA.

\begin{tabular}{|c|c|c|c|c|c|}
\hline \multicolumn{5}{|c|}{ Size distribution $(\mu \mathrm{m} / \mathrm{wt})$} & , Mean : $100 \mu \mathrm{m}$ \\
\hline+212 & $212 / 150$ & $150 / 106$ & $106 / 75$ & $75 / 53$ & -53 \\
\hline 0 & 10.8 & 32.0 & 32.8 & 12.5 & 11.9 \\
\hline
\end{tabular}

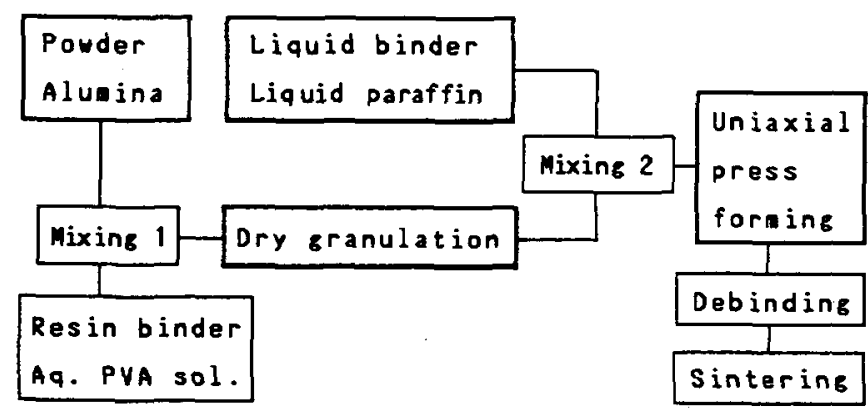

Fig.1 Process diagran of Press Powder Plow Compaction from alumina pouder.
をカップ底とカッフ壁とに切断分割後の各部の密度測 定による成形体内部の密度差について行った.脱パイ ンタは $350^{\circ} \mathrm{C} て ゙ 2 h r$ 保持する加熱分解法であり，焼結は $1480^{\circ} \mathrm{C}$ の $\mathrm{hr}$ 保持とした.

\section{3 実咉結果およひ考察}

\section{1 成形体内の密度分布}

Table 2 は各成形圧について流動パラフィンの添加 量を変化させて得られた成形体の外観を観察した結果 を示す. 流動バラフィンの添加量が多く，成形圧が高 い場合には成形体から流動バラフィンのしみ出しが起 る. Pig.3 は成形体全体の密度と流動パラフィン添加 量との関係を示す. 各成形圧について流動パラフィン の添加にともなう成形体密度の上昇か認められ，成形 圧が196MPaでは流動パラフインの添加量が7.5 wt\%の場 合に最高密度の成形体が得られた. 成形压が1964Pa， 294MPaで流動バラフィン添加量が 10wt\%の場合, 成形 体の密度が低下するのは，後述する成形体内の気孔事 （Fig.12）はほほOとなり，添加された流動パラフィ ンは成形体の密度上昇を抑制するためであると考えら れる。

Table 2 Evaluation to formability and defect of green compact by changing in compacting pressure and content of liquid paraffin.

\begin{tabular}{|c|c|c|c|c|c|}
\hline $\begin{array}{c}\text { Compacting } \\
\text { pressure } \\
\text { (MPa) }\end{array}$ & \multicolumn{5}{|c|}{ Content of liquid paraffin (wt\%) } \\
\cline { 2 - 6 } & 0 & 2.5 & 5.0 & 7.5 & 10.0 \\
\hline 98 & $\bigcirc$ & $\bigcirc$ & $\bigcirc$ & $\bigcirc$ & $\bigcirc^{*}$ \\
\hline 196 & $@$ & $\bigcirc$ & $\bigcirc$ & $\bigcirc$ & $\triangle^{*}$ \\
\hline 294 & $\bigcirc$ & $\bigcirc$ & $\bigcirc$ & $\bigcirc^{*}$ & $\bigcirc^{*}$ \\
\hline
\end{tabular}

(O): Good green compact formed

$\triangle$ :Cracking on cup wall

\#: Exuding liquid paraffin from green compact 
成形体内の密度分布を検討するため，得られた成形 体をカップ底とカップ壁とに切断分割し，カップ底と カッブ壁の密度を測定した結果はFig.4〜Fig.6に示す. 成形圧が98MPaの場合（Fig.4），流動パラフインの添 加にともないカップ底の密度は上昇するが，流動パラ フィンの添加量が 10wt\%では低下する. カップ壁の密 度は流動パラフィンの添加にともない上昇し，とくに 流動パラフィンの添加量が10wt％において急上昇を示 す. その結果, カップ底とカップ壁の密度差は著しく 減少した. 成形圧が 196MPa，294MPaの場合 (Fig.5, Fig.6）， 流動パラフィンの添加量に対するカップ底 およひカッブ壁の密度はある量の流動パラフィン添加

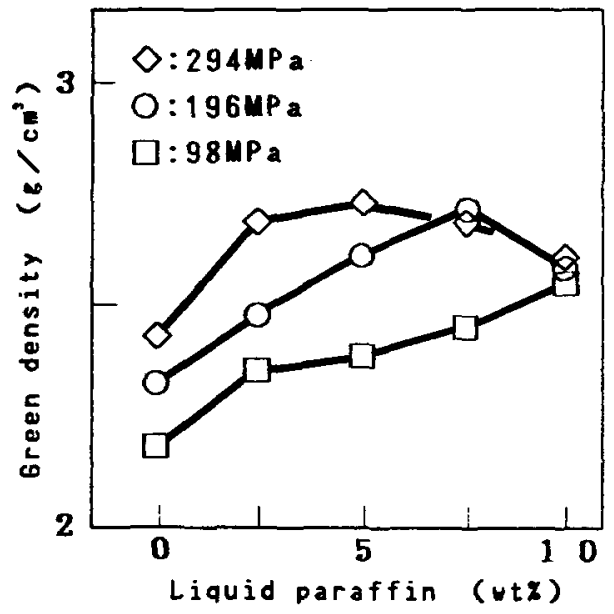

Fig.3 Relation between green density and content of liquid paraffin.

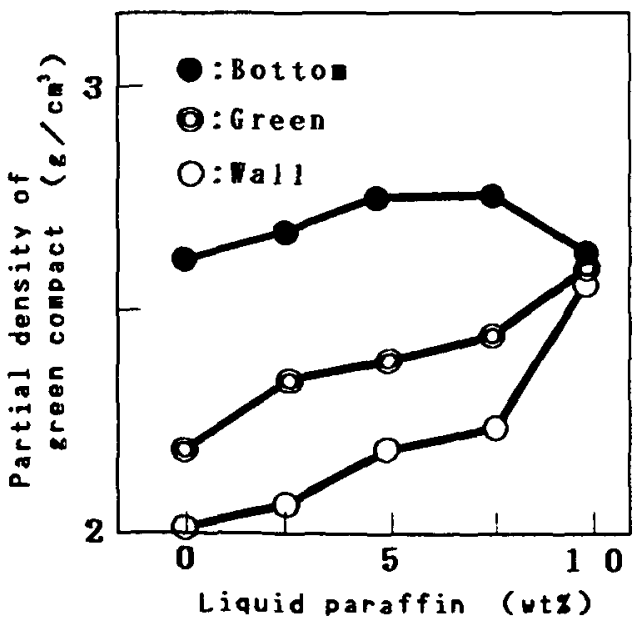

Fig.4 Relation between partial density of green compact and content of liquid paraffin. (Compacting pressure : 98KPa)
において最大值となった。実験結果から流動パラフィ ン添加量が 7.5wt\%, 10wt\%で成形体内の密度差は減少 することが分かった。

\section{2 粉末の流動性}

成形途中の粉末の流動性を検討するために成形体内 の密度尔布と成形圧との関係を示すとFig.7 Fig.9に なった. 流動パラフィンの添加なし，添加量が7.5wt\% および10wt\%の結果である.Fig.7に示した流動パラフ インの添加がない場合には，成形压が简い294MPaにお いてもカップ底とカップ壁との密度差は減少しない. Fig.9 に示した流動パラフィン添加量が 10wt\%では,

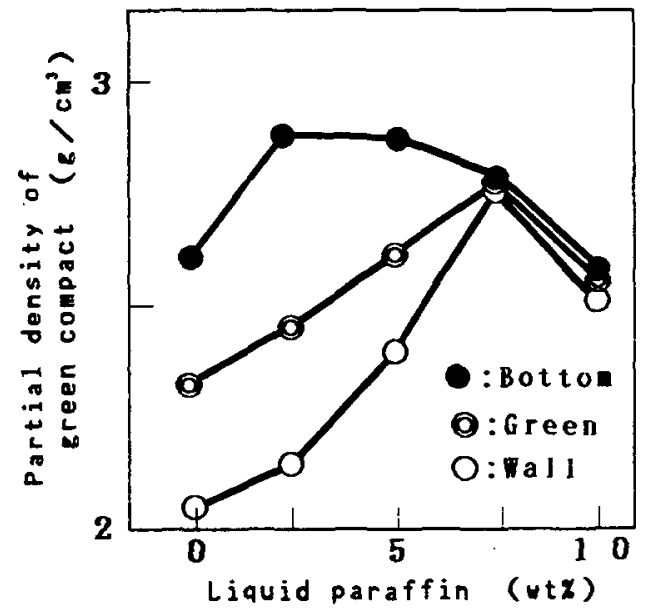

Fig.5 Relation between partial density of green compact and content of liquid paraffin. (Compacting pressure : 196MPa)

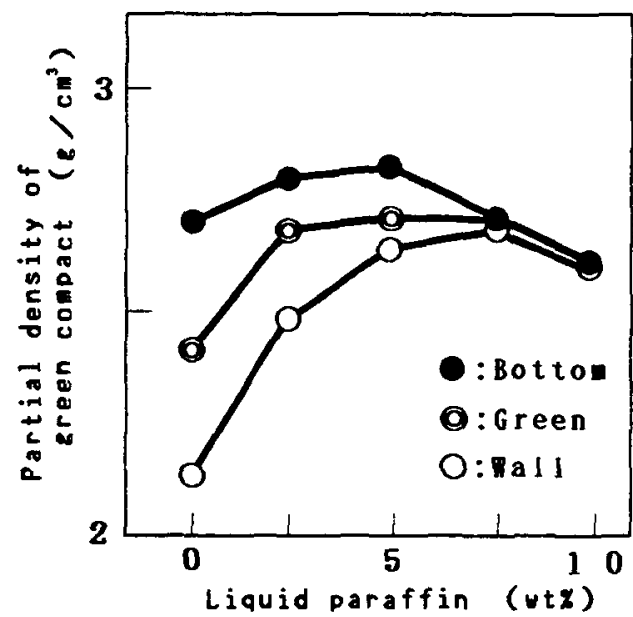

Fig.6 Relation between partial density of green compact and content of liquid paraffin. (Compacting pressure : 294MPa) 
各成形压において成形体内の密度差は著しく少ない。 流動パラフインの添加量が7.5wt\%の結果はFig.8 に示 し, 成形体内の密度差は成形王が1964Pa以上では少な い.

そこで䋛座標は成形体の部分密度とし，横座標は成 形体のカッフ底の厚さをとって図示したFig.10から粉 末の流動性を考察した。カップ底の厚さは成形压と負 の比例関係があり，成形压が高いほどカップ底は薄く なる.流動パラフィンの添加量が7.5wt\%の場合，カッッ 一底の厚さは成形压：98MPa0)5.4mmから, 成形压が上 帠して196MPaとなったときの $3.8 \mathrm{~mm}$ となり，カップ底

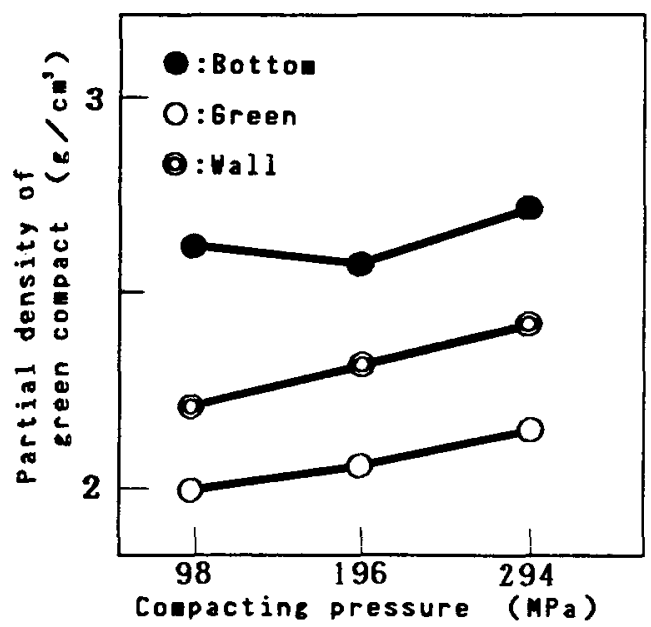

Fig.7 Relation between partial density of green compact and compacting pressure. (Liquid paraffin : 0 )

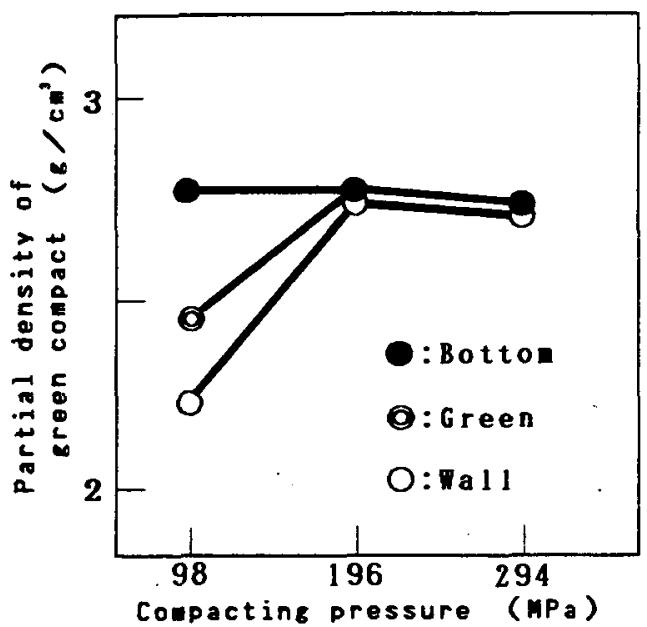

Fig. 8 Relation between partial density of green compact and compacting pressure. (Liquid paraffin : $7.5 \mathrm{wt}$ )
の密度変化は無視できるほど小さ（Fig.8）ことか ら，カップ底の粉末の約 30 wt\% はカップ壁に流動した ことが分かった。本実験の範囲内では，成形圧の上昇 （98MPaから 1964Paに上昇）にともなう粉末の流動は 流動パラフィンの添加量が7.5wt\%の場合に最大であつ た. また成形中における粉末の流動性を調査すること を目的に，成形実験に使用した金型て顆粒粉の圧粉試 験を行った. 流動パラフィンの添加量を変えてオート グラフによって測定したパンチストローク（压粉速度 ：1mm/min）と压粉圧力の線図をFig.11 に示す.流動 パラフィンの添加なしと比較して，添加量が7.5 wt\%,

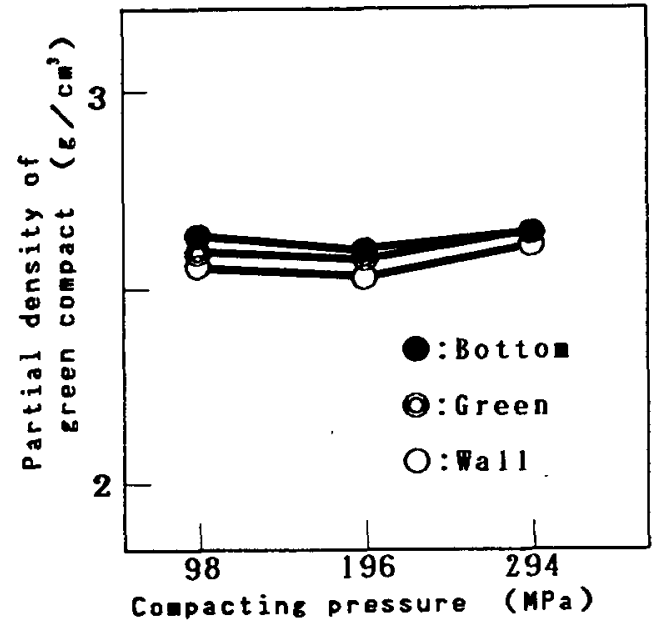

Fig.9 Relation between partial density of green compact and compacting pressure. (Liquid paraffin : 10wt\%)

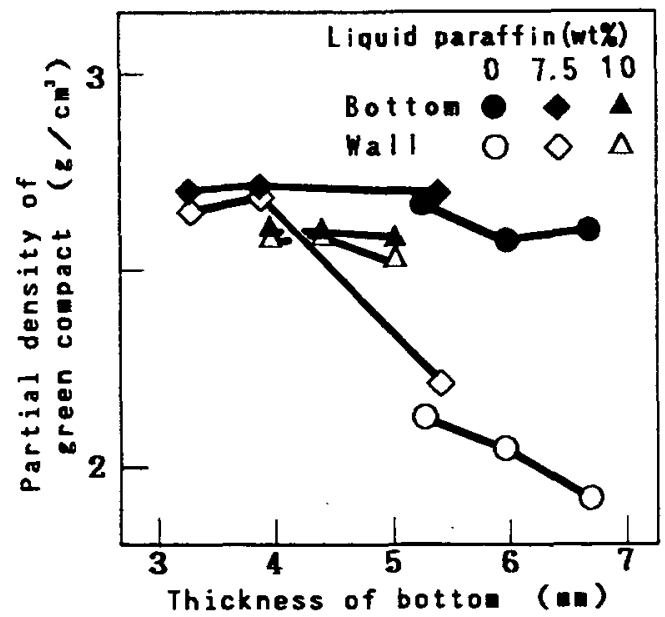

Fig.10 Relation between partial density of green compact and thickness of cup bottom by changing in content of liquid paraffin. 
10wt\%の線図は圧粉の途中において変曲点が認められ， パンチストロークに対する王粉圧力の上昇が一時的に 停湍する. 変曲点での圧粉圧力は流動パラフィンの添 加徨が7.5wt\%では110MPa，10wt\%では70MPaとなり，压 枌途中のこの変曲点で粉末の流動が始つたと考えられ る.

つきに流動パラフィンの添加量の増大にともなうパ インダの体積事を計算するとTable 3 となった。総パ インタ量（vol\%）は流動バラフインの添加量が 10wt\% では多量となる．しかし総バインタ量の約75\% は脱バ インダの容易な流動パラフィンである．また成形体内 の気孔事を成形体の密度から計算により求め, 成形体 の密度との関係を示すとPig.11になる. 流動パラフィ ンの添加量，成形圧の上舁とともに気孔本は減少し， Table 3 に示した流動パラフィンの体積事が気れ事の 減少量とほほ対応している．とくに成形体内の密度差 が著しく少なく, 成形体から流動パラフィンのしみ出 しが起る，流動パラフイン添加量が 10wt\%の各成形圧 での成形体およひ流動パラフィン添加量が7.5wt\%の成 形压：294MPaでの成形体では気孔率がほほ○となった。 成形体内の密度差が少ない成形体は気孔事も少ないこ とが分かった.このことは添加された流動パラフィン は成形時の粉末の流動に寄与し, 成形後は粉末間の気 れにほほ充渵していることを示している．すなわち， 成形体の気孔を埋める程度の流動パラフィン量が添加 された場合に成形体内の密度差が少ない成形体が得ら れたことを示している.

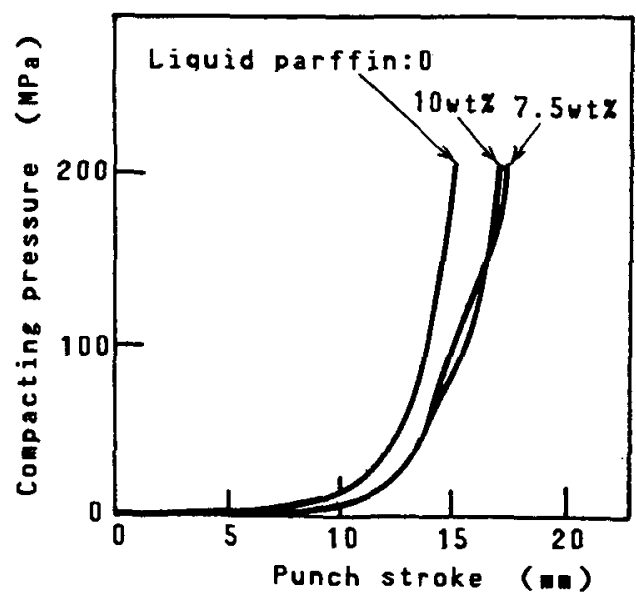

Fig.11 Diagram of compacting pressure-punch stroke by changing in content of liquid paraffin.

\section{3 烧結体の寸法精度}

成形体を脱バインダ後に烧結し，成形体と焼結体の 外観写真を Photo.1に示す. 焼結された成形体は寸法 が収縮し，焼結体の形状は流動バラフィンの添加の有 無によって特徵を持っている．流動パラフィンの添加 なしではカップの高さは大きく，カップの上縁部は他 の部分と比較して寸法の収樎が大きい，流動パラフィ ンの添加量が 7.5wt\%，10wt\%では焼結にともなう寸法 の収緶はほほ等しく見える．焼結体の密度はFig.13に 示し，相対密度は約 $90 \%$ とった。

つぎに，高さ方向に焼結体の直径を測定した結果は Fig.14，Fig.15に示す. 測定はカップの底からカップ の上縁までを 4 等分して行った。流動パラフィンの添 加量を変化させたFig.14の場合には，Photo.1で示し たように流動パラフィンの添加量が 7.5wt\%，10wt\%で

Table 3 Binder volume ratio of alumina granule with 3wt\% PVA and added liquid paraffin.

\begin{tabular}{|l|c|c|c|c|c|}
\hline & \multicolumn{5}{|c|}{ Liquid paraffin (wt\%/vol\%) } \\
\cline { 2 - 6 } & 0 & 2.5 & 5.0 & 7.5 & 10.0 \\
\hline Liquid paraffin & 0 & 8.6 & 16.1 & 22.9 & 28.9 \\
\hline PVA and others & 13.0 & 11.9 & 10.9 & 10.0 & 9.2 \\
\hline Total binder & 13.0 & 20.5 & 27.0 & 32.9 & 38.1 \\
\hline
\end{tabular}

PVA: $\rho=1$, Liquid paraffin: $\rho=0.9$

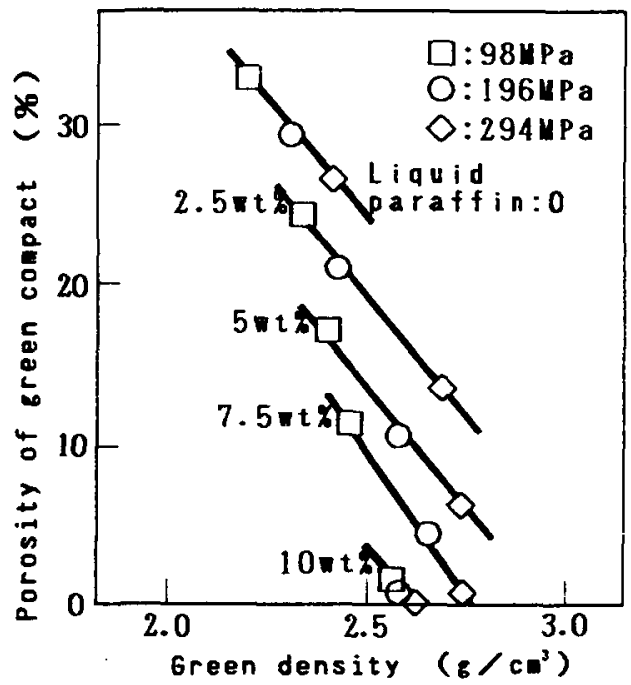

Fig.12 Relation between porosity of green compact and green density by changing in content of liquid paraffin and compacting pressure. 


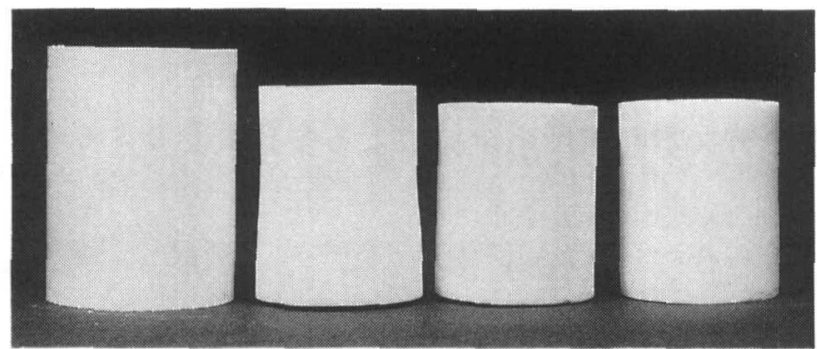

(a) Green compact LP:0

(b) Sintered compact LP:0

(c) Sintered compact LP:7.5wt\%

(d) Sintered compact LP: 10 wt\%

Photo.1 External appearance of green compact and sintered compact by changing in content of liquid paraffin. (Compacting pressure : $196 \mathrm{MPa}$, Sintering : $1480^{\circ} \mathrm{C} * 3 \mathrm{hr}$ )

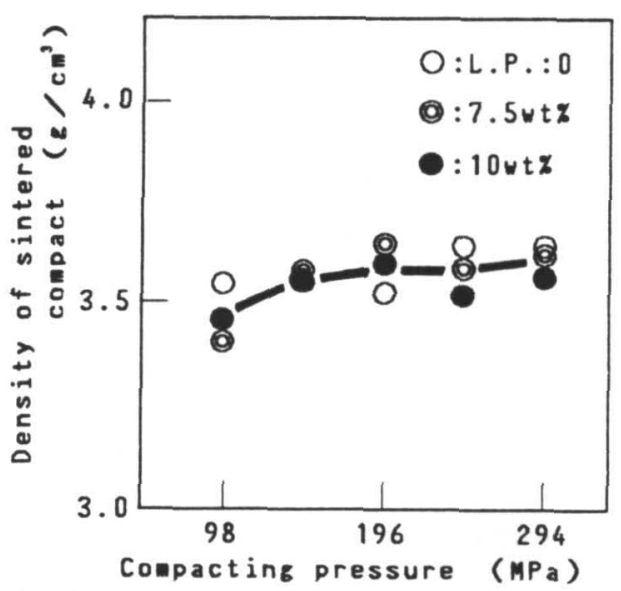

Fig.13 Relation between density of sintered compact and compacting pressure by changing in content of liquid paraffin.

(Sintering : $1480^{\circ} \mathrm{C} * 3 \mathrm{hr}$ )

は, 直径の相違は少ない. しかし流動パラフィンの添 加がない燒結体ではカップ底の直径が太く, カップ上 縁は細い．また流動パラフィンの添加量か57.5wt\%の場 合と 10wt\%の場合を比較すると, 流動パラフィンの添 加量が 10wt\%において直径は細い.これは焼結体の密 度が流動パラフィンの添加量に関係しないこと（Fig． 13）, 成形体の密度が流動パラフィンの添加量 $7.5 \mathrm{wt} \%$ で大きい結果 (Fig.5) による. 本成形法の特徵であ る成形体内の密度分布が少ないことは, 結果として焼 結体各部の寸法収縮を等しくし, 焼結体の寸法精度を 向上させた.

\section{4 おわりに}

アルミナ顆粒粉から加圧流動成形法によって薄肉力 ップを成形し, 成形体内の密度分布から成形中の粉末 流動を検討した.さらに成形体内の密度分布と焼結体

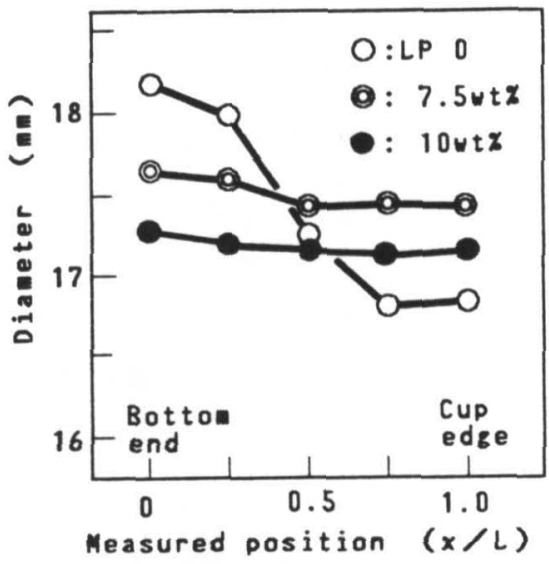

Fig.14 Diameter of sintered compact by changing in content of liquid paraffin. (Compacting pressure : 196MPa, Sintering : $1480^{\circ} \mathrm{C} * 3 \mathrm{hr}$ )

の寸法収縮を考察して以下の結果を得た。

1）流動パラフィンを添加したアルミナ顆粒粉の加圧 流動成形による成形体の密度は上昇した。

2）成形体のカップ壁密度は成形压の上昇および流動 パラフィンの適量添加によって急上昇し, 密度上 昇の少ないカップ底の密度との差は減少した。

3）流動パラフィンの添加量が7.5Wt\%, 成形圧を 196 $\mathrm{MPa}$ とした成形体は流動パラフィンのしみ出しな しで成形体内の密度差が著しく少ない.

4）密度分布の少ない成形体は焼結時の寸法収縮が均 一となり，焼結体の寸法精度が向上した。

\section{柺辞}

本研究を行うにあたりアルミナ顆粒粉を提供戴いた 高木産業(傲の関係各位に深謝いたします．また東大生 研中川研究室の安斎正博博士およひ野口裕之技官から 適宜助言を戴いたことに感謝します. 本研究は天田金 属加工機械技術振興財団の研究開発助成を受けたこと ことを記し深謝致します。

\section{文 献}

1）高橋清造, 中川威雄 : 粉体およひ粉末冶金, 38 (1991) 804

2）高橋清造，中川威雄 : 粉体およひ粉末冶金，39 (1992) 10.

3）高橋清造, 中川威雄 : 粉体粉末冶金協会平成 3 年 度秋季大会概要集，228。

4）高橋清造, 中川威雄 : 平成 4 年度塑性加工春季講 演論文集, 259. 